The Arab Journal of Scientific Research

http://aiesa.org/2017/09/the-arab-journal-of-scientific-research/

Effect of doxorubicin treatment at the

expression levels of $B C L-2$ and $B A X$ on MCF7

\section{cell line}

Mohammed H. Awwad ${ }^{1}$, Hayam ELSharawy ${ }^{1}$ and Fatma

Ashour $^{1}$

${ }^{1}$ Department of Zoology, Faculty of Science, University of

Benha, Benha, Egypt.

\section{Abstract}

Breast cancer (BC) is a chemotherapy sensitive tumor. Doxorubicin hydrochloride (DOX) is one of the most common chemotherapeutic drugs that used in breast cancer treatment. It intercalates with DNA and stops the replication process. And it was found that, following $48 \mathrm{~h}$ of DOX treatment, cell death Increases in $\mathrm{ER}^{+}$breast cancer cell lines. Here we investigated the effect of DOX treatment at the antiapoptotic $B C L-2$ and the proapoptotic $B A X$ genes. Methods: MCF7 cell line was cultured in the appropriate media and treated with DOX for 48 hours. Then the expression levels of $B C L-2$ and $B A X$ were investigated using qPCR. Results: the expression of $B C L-2$ showed a slight increase in its levels after treatment while $B A X$ gene showed a striking increase (3.62 fold). Conclusion: our results was in line with previous studies showed that treatment with DOX induce apoptosis in MCF7 cells.

\section{Introduction}

Breast undergoes a lot of pathological conditions that may be non-neoplastic (e.g: lesions) or neoplastic (e.g: breast carcinoma) (Bateman and Shaw 2013). Breast carcinoma (BC) is one of the most public reasons of cancer death in women all over the world (Ferlay, Shin et al. 2010). There are different types of $\mathrm{BC}$; the histological subtypes including ductal carcinoma and lobular carcinoma. Both ductal and lobular carcinoma may be either insitu or invasive (when it invades the surroundings) (Nazário, Facina et al. 2015). Also the molecular subtypes includes; $\mathrm{ER}^{+}$and $\mathrm{ER}^{-}$according to the status of estrogen receptors (ER) (Sotiriou, Neo et al. 2003). The response to drugs differs from $\mathrm{ER}^{+}$and $\mathrm{ER}^{-}$(Puhalla, Bhattacharya et al. 2012, Lippman and DICKSON'r 2013). Doxorubicin hydrochloride (DOX) is one of the most common chemotherapeutic drugs that used in BC treatment (Pritchard, Dillon et al. 2012). DOX has been shown to induce apoptosis (Sharma, Tyagi et al. 2004) and arrest cell cycle (Rusetskaya, Lukyanova et al. 2009).

$B C L-2$ is an anti-apoptotic gene which prevent cell death, Dole and Minn (1995) revealed that high expression levels of $B C L-2$ makes the cancer cells resist the apoptotic effect of chemotherapeutic drugs (Dole, Jasty et al. 1995, Minn, Rudin et al. 1995). In the other hand $B A X$ is a proapoptotic molecule that stimulate cell death, and its expression is not affected by estrogen treatment (Teixeira, 
Mohammed H. Awwad, Hayam ELSharawy and Fatma Ashour

Vol. 2

Reed et al. 1995). We study the effect of DOX treatment on the expression levels of these two genes in the $\mathrm{ER}^{+} \mathrm{MCF} 7$ breast cancer cell line.

\section{Methods}

\section{Cell line and Cell growth}

Human $\mathrm{ER}^{+}$breast cancer cell line MCF7 (VACSERA, Cairo, Egypt) was sustained in RPMI high glucose media (Lonza, Walkersville, MD, USA) complemented with $1 \%$ penicillin/streptomycin (Lonza, Walkersville, MD, USA), 10\% fetal bovine serum (Seralab, West Sussex, United Kingdom) and $25 \mu$ M HEPES (Lonza, Walkersville, MD, USA). Cells then cultivated in a humid incubator at $37^{\circ} \mathrm{C}$ and $5 \% \mathrm{CO}_{2}$.

\section{DOX treatment}

After reaching $70-80 \%$ confluence, cells then separated into two groups; Control (C) group: cells grown in fresh media and drug treated (D) group: cells grown in fresh media treated with DOX at final concentration of $1 \mu \mathrm{M}$. Also we added 17- $\beta$ estradiol (Sigma Aldrich, St. Louis, MO, USA) used at final concentration of $10 \mathrm{nM}$ to activate estrogen receptor. Cells were treated for $48 \mathrm{~h}$.

\section{RNA Extraction and cDNA Synthesis}

RNA was then extracted by means of iTRAZOL reagent (ITSI Biosciences, Johnstown, PA, USA) by following steps in its pamphlet. Using Revert aid first strand cDNA kit (Thermo Fisher scientific, Waltham, MA, USA) we then synthesed the cDNA also by following steps in its pamphlet.

\subsection{Real time PCR}

Using Quantitect SYBR green PCR kit (QIAGEN, Hilden, Germany), the reactions were prepared and carried out using Real time PCR machine (MX3005P Stratagene, San Diego, CA, USA) with the following cycling conditions: 40 cycles of denaturation at $94^{\circ} \mathrm{C}$, annealing at temperatures mentioned in table 1 depending on the gene and final extension at $72^{\circ} \mathrm{C}$. Using GAPDH as housekeeping, we detected changes in gene expression with relative quantification method $(\Delta \Delta \mathrm{Ct})$ with these equations:

Gene expression (amount of target) $=2^{-\Delta \Delta C t}$

$$
\begin{aligned}
& \Delta \Delta \mathrm{Ct}=\Delta \mathrm{Ct}_{\text {sample }}-\Delta \mathrm{Ct} \text { calibrator } \\
& \Delta \mathrm{Ct}=\mathrm{Ct} \text { tested gene }-\mathrm{Ct}_{\text {house keeping }}
\end{aligned}
$$

Table 1: primers of genes under study

\begin{tabular}{|c|c|c|c|}
\hline Gene & $\begin{array}{c}\text { Forward } \\
\text { primer(5' to 3') }\end{array}$ & $\begin{array}{c}\text { Reverseprimer(5 } \\
\text { 'to 3') }\end{array}$ & $\begin{array}{c}\text { Melting } \\
\text { temperature }\end{array}$ \\
\hline GAPDH & $\begin{array}{c}\text { TGATGACATC } \\
\text { AAGAAGGTGG } \\
\text { TGAAG }\end{array}$ & $\begin{array}{c}\text { TCCTTGGAGGC } \\
\text { CATGTGGGCC } \\
\text { AT }\end{array}$ & $52^{\circ} \mathrm{c}$ \\
\hline BAX & $\begin{array}{c}\text { GCCCTTTTGCT } \\
\text { TCAGGGTTTC }\end{array}$ & $\begin{array}{c}\text { CTGATCAGTTC } \\
\text { CGGCACCTT }\end{array}$ & $62^{\circ} \mathrm{c}$ \\
\hline BCL-2 & GAACTGGGGG & CATCCCAGCCT \\
AGGATTGTGG & CCGTTATCC & $56{ }^{\circ} \mathrm{c}$ \\
\hline
\end{tabular}




\section{Results}

Expression levels of $B C L-2, B A X$ increase in the $\mathrm{ER}^{+}$ MCF7 cells after DOX treatment.

We found that DOX treatment increased the expression levels of $B C L-2$ and $B A X$ after $48 \mathrm{~h}$ of treatment. $B C L-2$ showed 1.71 fold change in its expression after $48 \mathrm{~h}$ of DOX treatment. Similarly $B A X$ showed 3.63 fold change in its expression after $48 \mathrm{~h}$ of treatment (figure 1).

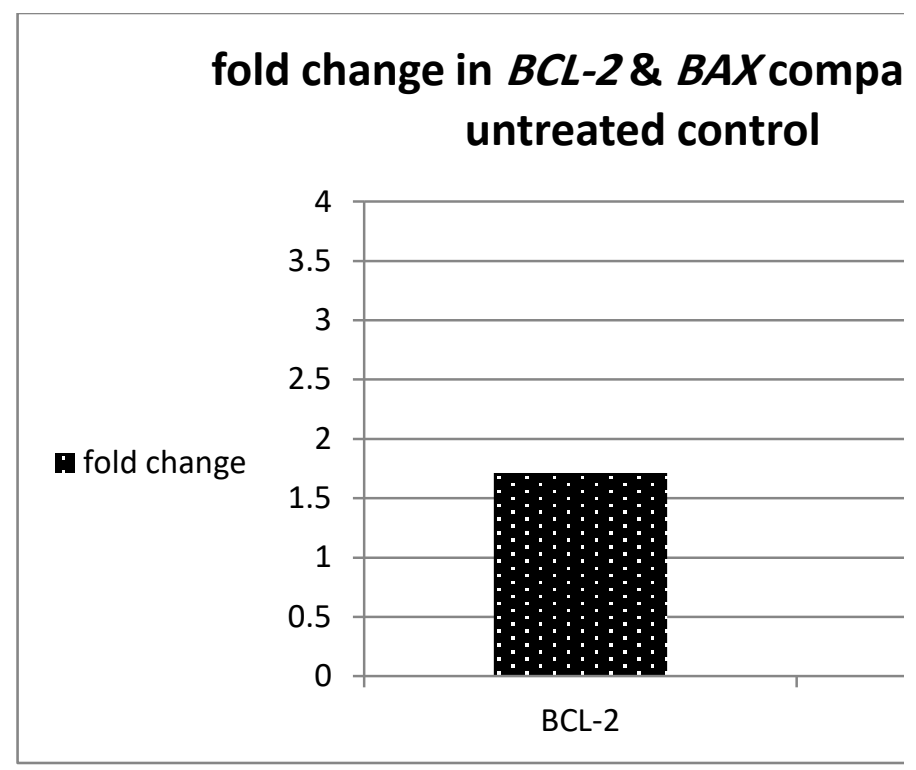

Figure 1: Gene expression of $B C L-2$ and $B A X$ in MCF7 cells after $48 \mathrm{~h}$ DOX treatment. Cells were incubated with $1 \mu \mathrm{M}$ DOX for $48 \mathrm{~h}$. Changes in gene expression of $B C L-2$ and $B A X$ after treatment were detected. They showed increase in their expression after $48 \mathrm{~h}$ of treatment.

\section{Discussion}

Doxorubicin hydrochloride is one of the most commonly used chemotherapeutic agents in $\mathrm{BC}$ management(Pritchard, Dillon et al. 2012). In BC cell lines a dose of $\geq 1 \mu \mathrm{M}$ of DOX decreases cell viability, promotes apoptosis and stops the cell cycle(Sharma, Tyagi et al. 2004, Lüpertz, Wätjen et al. 2010). Here we tested the effect of DOX treatment on $\mathrm{ER}^{+} \mathrm{MCF} 7$ cell lines and how it alters the mRNA $B C L-2$ and $B A X$.

When the cells were exposed to the drug for $48 \mathrm{~h}$, we have found that the expression of BCL-2 in was increased. But this contrast with other studies revealed that DOX down regulates $B C L-2$ mRNA levels (Mcgahon, Costa Pereira et al. 1998, Leung and Wang 1999). The difference between our finding and these studies could be because those studies revealed the action of DOX alone but in our study we treated the cells with estrogen to activate estrogen receptors. Indeed estrogen was shown to reverse the action of DOX alone and increase BCL-2 levels (Teixeira, Reed et al. 1995). And this agrees with Lacroix and Leclercq (2004) who showed that active ER $\alpha$ prevents apoptosis of breast cancer cells via increasing the expression levels of BCL-2(Lacroix and Leclercq 2004).

We also found that the expression of BAX increased tremendously after treatment with DOX. Our BAX data is in line with other studies showed that BAX is a pro-apoptotic molecule motivates cell death and is overexpressed in MCF7 cells after treatment with DOX(Leung and Wang 1999, Sharifi, Barar et al. 2015) and 
Mohammed H. Awwad, Hayam ELSharawy and Fatma Ashour

Vol. 2

its expression is not affected by estrogen

treatment(Teixeira, Reed et al. 1995).

It was found that, following $48 \mathrm{~h}$ of DOX

treatment, cell death Increases in $\mathrm{ER}^{+}$breast cancer cell

lines (Sharma, Tyagi et al. 2004) and although we showed that the mRNA expression levels of $B C L-2$ and $B A X$ are increased in $\mathrm{ER}^{+} \mathrm{MCF} 7$ cells, it is not clear whether this change may lead to apoptosis or not. More studies investigating the gene expression profiles and apoptotic and viability assays of MCF7 are recommended to identify the final fate of the cells after DOX treatment. 


\section{References}

Bateman, A. C. and E. C. Shaw (2013). "Breast pathology." Surgery (Oxford) 31(1): 4-10.

Dole, M. G., R. Jasty, M. J. Cooper, C. B. Thompson, G. Nuñez and V. P. Castle (1995). "Bcl-xL is expressed in neuroblastoma cells and modulates chemotherapy-induced apoptosis." Cancer research 55(12): 2576-2582.

Ferlay, J., H. R. Shin, F. Bray, D. Forman, C. Mathers and D. M. Parkin (2010). "Estimates of worldwide burden of cancer in 2008: GLOBOCAN 2008." International journal of cancer 127(12): 2893-2917.

Lacroix, M .and G. Leclercq (2004). "Relevance of breast cancer cell lines as models for breast tumours: an update." Breast cancer research and treatment 83(3): 249-289.

Leung, L. K. and T. T. Wang (1999). "Differential effects of chemotherapeutic agents on the $\mathrm{Bcl} / \mathrm{T}$-Bax apoptosis pathway in human breast cancer cell line MCF-7." Breast cancer research and treatment 55(1): 73-83.

Lippman, M. E. and R. B. DICKSON'r (2013). Mechanisms of growth control in normal and malignant breast epithelium. Recent Progress in Hormone Research: Proceedings of the 1988 Laurentian Hormone Conference, Academic Press.

Lüpertz, R., W. Wätjen, R. Kahl and Y. Chovolou (2010). "Dose-and time-dependent effects of doxorubicin on cytotoxicity, cell cycle and apoptotic cell death in human colon cancer cells." Toxicology 271(3): 115-121.

Mcgahon, A. J., A. P. Costa Pereira, L. Daly and T. G. Cotter (1998). "Chemotherapeutic drug-induced apoptosis in human leukaemic cells is independent of the Fas (APO-1/CD95) receptor/ligand system." British journal of haematology 101(3): 539-547

Minn, A. J., C. M. Rudin, L. H. Boise and C. B. Thompson (1995). "Expression of bcl-xL can confer a multidrug resistance phenotype." Blood 86(5): 1903-1910.

Nazário, A. C. P., G. Facina and J. R. Filassi (2015). "Breast cancer: news in diagnosis and treatment." da Associação Médica Brasileira 61(6): 543-552.

Pritchard, J. E., P. M. Dillon, M. R. Conaway, C. M. Silva and S. J. Parsons (2012). "A mechanistic study of the effect of doxorubicin/adriamycin on the estrogen response in a breast cancer model." Oncology 83(6): 305-320.

Puhalla, S., S. Bhattacharya and N. E. Davidson (2012). "Hormonal therapy in breast cancer: a model disease for the personalization of cancer care." Molecular oncology 6(2): 222-236.

Rusetskaya, N., N. Y. Lukyanova and V. Chekhun (2009). "Molecular profile and cell cycle in MCF-7 and MCF7/Dox cells exposed to conventional and liposomal forms of doxorubicin." Exp Oncol 31: 140-143.

Sharifi, S., J. Barar, M. S. Hejazi and N. Samadi (2015 .) "Doxorubicin changes Bax/Bcl-xL ratio, caspase- 8 and 9 in breast cancer cells." Advanced pharmaceutical bulletin 5(3): 351 .

Sharma, G., A. K. Tyagi, R. P. Singh, D. C. Chan and R. Agarwal (2004). "Synergistic anti-cancer effects of grape seed extract and conventional cytotoxic agent doxorubicin against human breast carcinoma cells." Breast cancer research and treatment $85(1)$ : 1-12.

Sotiriou, C., S.-Y. Neo, L. M. McShane, E. L. Korn, P. M. Long, A. Jazaeri, P. Martiat, S. B. Fox, A. L. Harris and E. T. Liu (2003). "Breast cancer classification and prognosis based on gene expression profiles from a population-based study." Proceedings of the National Academy of Sciences 100(18): 10393-10398.

Teixeira, C., J. C. Reed and M. C. Pratt (1995). "Estrogen promotes chemotherapeutic drug resistance by a mechanism involving Bcl-2 proto-oncogene expression in human breast cancer cells." Cancer research 55(17): 3902-3907. 